Open Access

\title{
Demand relationships in orange exports to Russia: a differential demand system approach focusing on Egypt
}

\author{
Assem Abu Hatab ${ }^{1,2}$
}

\author{
Correspondence: \\ assem.abouhatab@gmail.com \\ ${ }^{1}$ Department of Economics and \\ Rural Development, Faculty of \\ Environmental Agricultural Sciences, \\ Arish University, Al-Arish, Egypt \\ ${ }^{2}$ Department of Economics, \\ Swedish University of Agricultural \\ Sciences, Ulls Väg 27, Box 7013750 \\ 07 Uppsala, Sweden
}

\begin{abstract}
Recent years have witnessed closer diplomatic relations between Egypt and Russia, which have led to significant growth in the countries' bilateral agricultural trade. As a world-leading producer and exporter of oranges, these developments represent an opportunity for Egypt to promote its orange exports to Russia. Another emerging opportunity for Egypt to increase its share in the Russian market for imported oranges has been provided by import embargos imposed by Russia in recent years on agricultural and food commodities from several countries, creating a supply gap of around $25 \%$ in the Russian orange market. To assess the competitiveness of Egyptian oranges and explore the potential export opportunities presented by the Russian market, this paper uses a Rotterdam import allocation model to analyse demand relationships among major orange suppliers to Russia during the period 1996-2014. The results show that in comparison with other orange suppliers, Egypt enjoys a strong comparative advantage in the export of oranges to Russia. The econometric results suggest that both Morocco and Egypt would benefit the most if Russia were to allocate a larger budget to the import of oranges. The expenditure elasticity estimates indicate that an increase in Russia's demand for imported oranges would lead to increases in the quantity of Egypt's orange exports, as well as in its share of the Russian orange market. Furthermore, cross-price elasticity estimates reveal that Egyptian oranges are substitutes for Turkish and South African oranges, implying that Russia has a tendency to switch to these two suppliers when Egyptian oranges become relatively expensive. In light of these results, the adoption of strategies to produce oranges sustainably and cost-effectively, upgrade the orange value chain, acquire processing technologies and enhance the technical and organisational capacity of farmers and exporters could be useful means for promoting exports and boosting the competitiveness of Egyptian oranges on the Russian market.
\end{abstract}

Keywords: Egyptian orange exports, Russia, Import demand, Differential demand system, Rotterdam model

JEL Classification: F14, Q11, Q17

\section{Background}

Fuelled by an increase in real disposable incomes over the past two decades and the growing tendency among domestic consumers to maintain healthier diets, the demand for fresh fruit and vegetables among Russian consumers has grown significantly in recent years (Honkanen and Voldnes 2006; Kolchevnikova 2010; Hamza 2015). With a share of around $7 \%$ of the fruit market, oranges are the second most popular citrus

(c) The Author(s). 2016 Open Access This article is distributed under the terms of the Creative Commons Attribution 4.0 International License (http://creativecommons.org/licenses/by/4.0/), which permits unrestricted use, distribution, and reproduction in any medium, provided you give appropriate credit to the original author(s) and the source, provide a link to the Creative Commons license, and indicate if changes were made. 
fruit in Russia (Ilyina 2011). The Russian orange market depends entirely on imports since oranges are not grown domestically, with the country having the largest share (around $12 \%$ ) of world orange imports (GRC 2012). Between 1996 and 2014, Russia's orange imports have grown by an average of $4.6 \%$ annually, rising from 257.5 thousand tons to around 469 thousand tons (WITS 2016).

Egypt, the world's sixth largest producer and second largest exporter of oranges, has always been one of the main orange suppliers to the Russian market (Hamza 2014). Particularly since 2001, Russia's orange imports from Egypt have increased substantially, skyrocketing from about 8 thousand tons in 2001 to 76 thousand tons in 2003 (Fig. 1). Between 2004 and 2010, the quantity of Russian orange imports from Egypt practically doubled, rising from 110 thousand tons to almost 219 thousand tons. Despite the socio-political unrest in Egypt in 2011, which adversely impacted its foreign trade sector, Egypt's orange exports to Russia have shown relative resilience and have generally continued to grow in the period after 2011 (Fig. 1).

Generally, this very strong performance of Egyptian orange exports on the Russian market can be attributed to the special attention that Egyptian agricultural policies have paid to the development of the orange supply chain at all levels. Such attention is motivated by the very significant contribution made by oranges to the country's fruit production (one third of total fruit production) and exports (around $10 \%$ of total agricultural exports worldwide) (Hamida 2012; WITS 2016). Furthermore, the promotion of orange exports to Russia has always been an objective of Egypt's agricultural export development strategies aimed at diversifying the map of the country's agricultural exports and reducing its dependency on a limited number of EU and Arab markets. Moreover, the importance of Russia as a target market for Egyptian orange exports has recently increased. Abu Hatab and Nsanimana (2016) indicate that "political proximity" between Egypt and Russia in recent years has revitalised their bilateral agricultural trade relations significantly. Thanks to several trade agreements being signed by the two countries to promote a greater level of trade liberalisation, bilateral agricultural trade has grown from USD 85 million in 1996 to about USD 2.2 billion in 2014, making Russia a major trading partner of Egypt (Parker 2015; WITS 2016). In this context and given Egypt's position in the global orange market, oranges have repeatedly been cited by Egyptian agricultural trade policymakers as an area in which the country could benefit from these improved bilateral agricultural trade

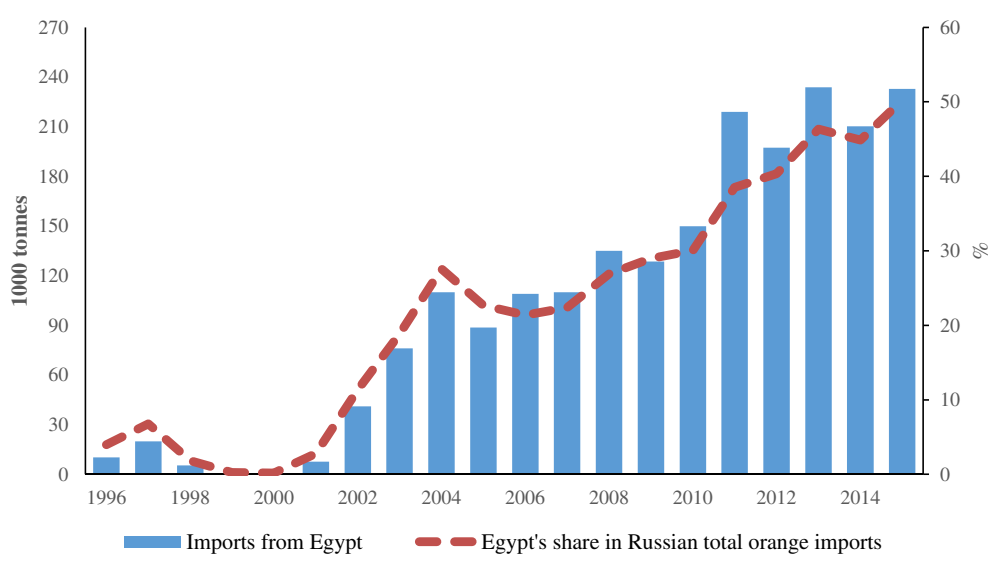

Fig. 1 Russian orange imports from Egypt, 1996-2015. Source: World Bank, WITS (2015) 
relations with Russia and secure a greater foothold in the Russian market for imported oranges.

In addition to these recent improvements in Egypt-Russia bilateral agricultural trade, the recent embargos imposed by Russia on agrifood imports from several destinations, including the EU in 2014 and Turkey in 2015, opened up another opportunity for the promotion of Egyptian orange exports to Russia (Hamza 2014). According to Abu Hatab and Nsanimana (2016), these two embargos have created a supply gap of about $25 \%$ in the Russian market, providing export opportunities to Egypt and other orange suppliers to fill the resulting import void. Although it is too early to assess the impacts of these embargos on Egyptian orange exports to Russia, Fig. 1 shows that there has been an increase of around $11 \%$ in the quantity of Egyptian oranges exported to Russia in 2015 in comparison with the preceding year.

To assess the competitiveness of Egyptian oranges and explore the export opportunities that the Russian market may offer Egyptian oranges, the present study used a sourcedifferentiated approach within a Rotterdam import allocation model to analyse the Russian demand for imported oranges from Egypt and other major suppliers during the period 1996-2014. This paper contributes to the literature in the following ways. First, especially in light of the above developments in Egyptian-Russian bilateral agricultural trade relations as well as the structural changes in the Russian market for imported oranges following the imposed import bans, the subject covered by this paper is very timely and its results could be useful to Egyptian agricultural trade policymakers in the development of informed strategies for the promotion of orange exports to Russia. Second, a closer look at the existing literature on the foreign demand for Egyptian agricultural exports shows that the majority of previous studies have ignored horticultural commodities in favour of other agrifood commodity groups, despite the fact that horticultural commodities are progressively making up an important proportion of Egyptian agricultural exports. Third, previous related empirical studies mainly focus on the EU, USA, and Arab markets, while few studies have so far investigated the demand for Egyptian agricultural exports in Russia and other Eastern European countries. This paper therefore attempts to fill this void in the literature by providing empirical evidence based on the analysis of the Russian demand for imported oranges from major suppliers including Egypt.

The next section in this paper provides a brief assessment of the competitiveness of Egyptian orange exports on the Russian market. This is followed by a presentation of the econometric model and a description of the data and their sources. The econometric results and the estimated demand elasticities are presented thereafter followed by a discussion of the results and concluding remarks.

\section{Assessing the competitiveness of Egyptian orange exports on the Russian market}

Several studies have shown that Egyptian oranges enjoy greater competitiveness factors relative to their rivals on the Russian market (Soliman and Bassiony 2012; Soliman 2013; Torayeh 2013; Hamza 2015). A recent USDA report by Hamza (2015) points out that Egyptian oranges traditionally enjoy a set of characteristics that include favourable production conditions, low labour costs and well-established supply chains, which collectively enhance their competitiveness on the Russian market. Specifically in terms of production capacity, recent statistics from MALR (2015) point out that oranges 
comprise almost half of the total area under fruit cultivation in Egypt. Egyptian orange production increased from 1.6 million tons in 1996 to around 3 million tons in 2014, recording an average annual growth rate of $3.6 \%$ (FAOSTAT 2016). It is worth mentioning that Egypt produces a wide range of orange varieties, including Baladi (domestic), Sukkari (the sweet orange), Valencia, blood orange and Navel. However, both Valencia and Navel varieties represent the major export varieties, whereas other varieties are mainly consumed domestically (MALR 2013).

With respect to product quality and consumer preferences, Rudolf (2015) shows that despite the fact that other competitors (e.g. Turkey and Greece) have a more favourable geographical position with regard to their proximity to the Russian market, the competitiveness of Egyptian oranges on the Russian market relies primarily on their quality and price. Soliman (2013) assessed the competitiveness of Egyptian fresh oranges in a number of European markets, including Russia, using the global value chain analysis approach (GVCA) based on interviews with buyers and key stakeholders in these markets. His results suggest that Egyptian oranges are perceived to be of higher quality than oranges from Turkey and Morocco. Moreover, unlike many other competing countries and due to favourable climatic conditions, Egyptian Valencia oranges do not normally experience the "re-greening phenomenon" which breaks down the colour dyes that give oranges their normal colour, causing a greenish tint, i.e. the reappearance of chlorophyll in mature oranges (Abu Hatab and Nsanimana 2016). Increased health concerns among consumers in Russian and other importing markets and fears of the use of chemicals to re-colour oranges therefore result in a high demand for Egyptian oranges on the Russian market.

With regard to export prices, Hassan et al. (2010) compared the export prices of Egyptian oranges with the export prices of other Mediterranean competitors, namely Spain, Israel, Morocco and Turkey. They concluded that Egyptian export prices of oranges are on average approximately $26 \%$ lower than the export prices of these competitors. Furthermore, using annual time series data covering the period 1981-2010, Soliman (2013) found that the average farm prices of Egyptian oranges have usually been lower than the corresponding average world price and that the export price of Egyptian oranges is lowest compared with the prices of traditional competitors such as Morocco, Syria, Tunisia and Turkey. The lower prices of Egyptian oranges further enhance their competitiveness in cost-conscious and heterogeneous markets such as the Russian market. Another important factor that gives Egyptian oranges a competitive edge on the Russian market comes from their early harvest compared to other major producers in the region, thus allowing Egyptian oranges an export season from midNovember to the end of August (Hamza 2015).

To develop a clearer picture of the Russian market for imported oranges, Fig. 2 portrays the distribution of major orange suppliers to Russia during the period 1996-2014. With an average import budget share of about $22.3 \%$, Morocco tops the list of major orange suppliers to the Russian market. Egypt ranks second, with an average expenditure share of $20.8 \%$. South Africa comes third (18.5 \%) followed by Turkey (15.4\%), while Greece and Argentina lag behind with average budget shares of around 7 and $5 \%$, respectively. Collectively, these six countries supplied the Russian market on average with nearly $89 \%$ of its total orange imports during the period 1996-2014. The empirical analyses in this paper therefore focused on these orange suppliers. 


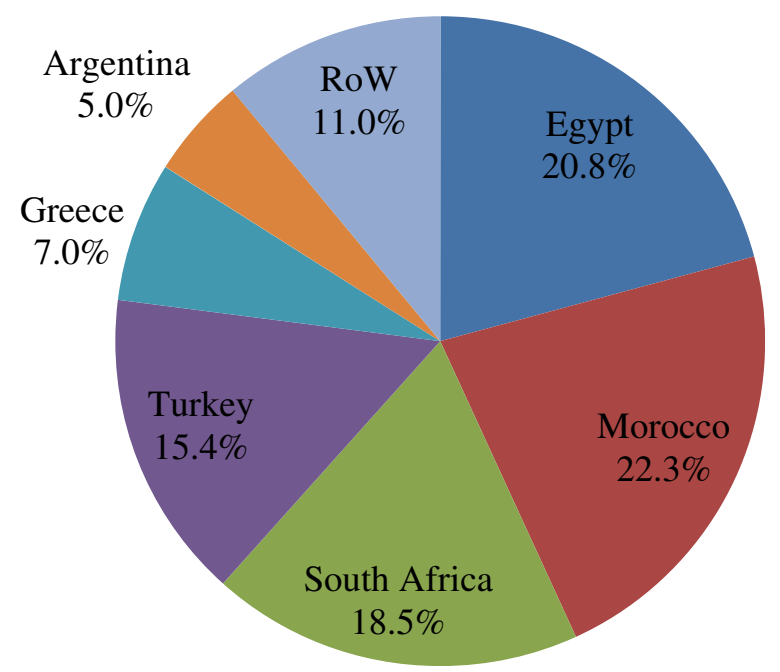

Fig. 2 Russian orange imports by the major country of origin, average 1996-2014. Source: World Bank, WITS (2016)

A closer look at Fig. 3, particularly in the years after 2000, reveals that the budget shares of these major orange suppliers to Russia have experienced dramatic changes over time. For instance, Morocco's budget share declined from about $49 \%$ in 2000 to just $5.4 \%$ in 2014. Albeit from a much lower starting point, Egypt's budget share has, in contrast, increased substantially, from nearly $3 \%$ in 2001 to around $44 \%$ in 2014. In particular, Egypt's share largely surpassed that of other major orange suppliers to Russia during the period 2007-2014, averaging roughly $40 \%$. With respect to the budget

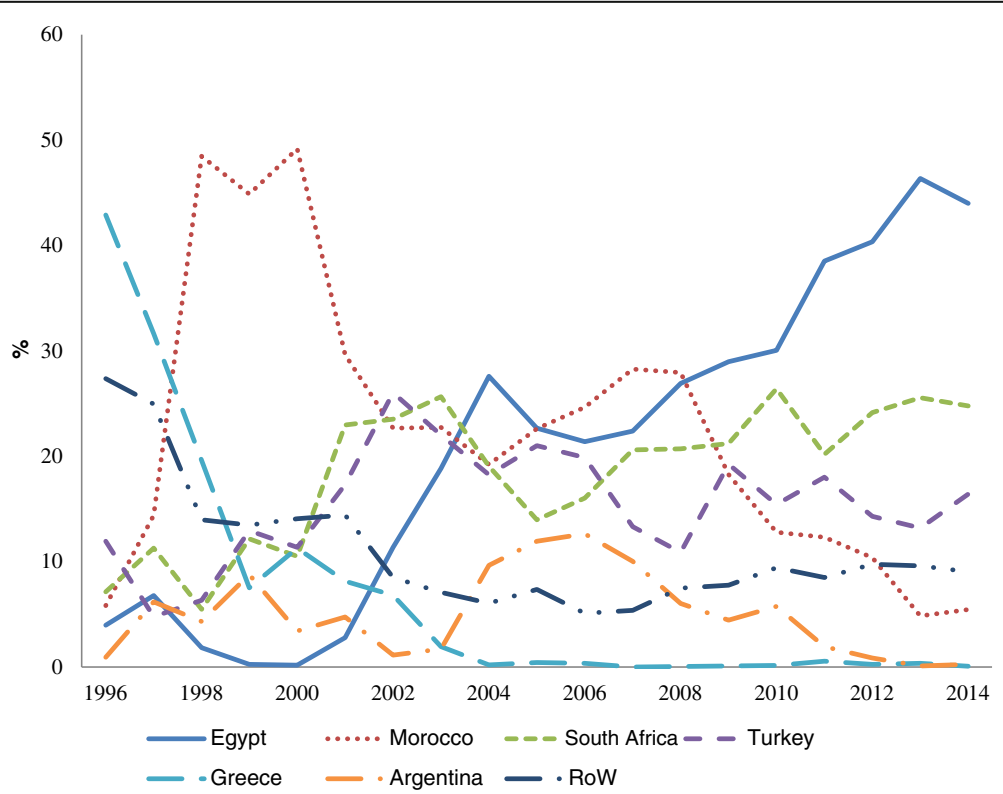

Fig. 3 Trends in the budget share of major orange suppliers to the Russian market, 1996-2014. Source: World Bank, WITS (2015) 
shares of other suppliers, Fig. 3 shows that they have been largely unchanged, with minor increases and decreases over the period 2000-2014.

To undertake an empirical assessment of the competitiveness of Egyptian oranges, the economic literature suggests that several approaches based on trade data can be used to measure international competitiveness. Originally, the concept of revealed comparative advantage (RCA) was introduced by Balassa (1965). Balassa's RCA index states that a given country has a comparative advantage (disadvantage) in a commodity when the commodity's exports market size in terms of its total exports market size is greater (less) than the commodity's world exports market size in terms of the world total exports market size, i.e. when the value of the index is greater (less) than unity (Abu Hatab and Romstad, 2014). Due to criticisms of Balassa's RCA index (e.g. Laursen 2015 and Leromain and Orefice 2014), Vollrath (1991) introduced three alternative indexes to measure a country's RCA. The first index is the relative trade advantage $\left(\mathrm{RTA}_{\mathrm{ad}}\right)$, which is calculated as the difference between relative export advantage (or Balassa's RCA index) $\left(\mathrm{RXA}_{\mathrm{ad}}\right)$ and relative import advantage $\left(\mathrm{RMA}_{\mathrm{ad}}\right)$ :

$$
\mathrm{RTA}_{\mathrm{ad}}=\mathrm{RXA}_{\mathrm{ad}}-\mathrm{RMA}_{\mathrm{ad}}
$$

where

$$
\mathrm{RXA}_{\mathrm{ad}}=\left(X_{\mathrm{ad}} / X_{\mathrm{na}}\right) /\left(X_{\mathrm{dr}} / X_{\mathrm{nr}}\right)=\text { Balassa's RCA index }
$$

and

$$
\mathrm{RMA}_{\mathrm{ad}}=\left(M_{\mathrm{ad}} / M_{\mathrm{na}}\right) /\left(M_{\mathrm{dr}} / M_{\mathrm{nr}}\right)
$$

While $X_{\text {ad }}$ represents the exports of commodity $d$ by country $a, X_{\text {na }}$ represents the exports of all commodities, excluding commodity $d$, by country $a$; $X_{\mathrm{dr}}$ is the exports of commodity $d$ by the rest of the world, excluding country $a$; $X_{\mathrm{nr}}$ is the exports of all commodities, excluding commodity $d$, by all countries in the world excluding country $a ; M_{\mathrm{ad}}$ represents the imports of commodity $d$ by country $a ; M_{\mathrm{na}}$ represents the imports of all commodities, excluding commodity $d$, by country $a ; M_{\mathrm{dr}}$ is the imports of commodity $d$ by the rest of the world; and $M_{\mathrm{nr}}$ is the imports of all commodities, excluding commodity $d$, by all countries in the world excluding country $a$.

The second index introduced by Vollrath is the natural logarithm of the relative export advantage $\left(\ln R X A_{a d}\right)$, while the third measure is the revealed competitiveness $\mathrm{RC}_{\mathrm{ad}}$ defined as follows:

$$
\mathrm{RC}_{\mathrm{ad}}=\operatorname{Ln}\left(\mathrm{RXA}_{\mathrm{ad}}\right)-\operatorname{Ln}\left(\mathrm{RMA}_{\mathrm{ad}}\right)
$$

Vollrath (1991) points out that positive (negative) values of lnRXA, RTA and RC indicate a revealed competitive advantage (disadvantage). The results of Vollrath's indices of revealed competitive advantage for Egypt and other major suppliers of oranges to Russia are summarised in Table 1. As an average of the period 1996-2014, the results indicated that Egypt had the highest relative export advantage index (Balassa's RCA index) value, implying a greater revealed comparative advantage in the export of oranges in comparison to other competitors on the Russian market. However, the results suggested that Egypt's RXA for oranges has been fluctuating over the years. Morocco's orange RXA has shown a decreasing trend, declining from 34.9 in 1996 to around 5.8 in 2014, implying a reduction in orange competitiveness. With respect to 
Table 1 Vollrath's indices of revealed competitive advantage for Egypt and other major orange suppliers to Russia

\begin{tabular}{|c|c|c|c|c|c|c|}
\hline & Morocco & Argentina & Egypt & Greece & Turkey & South Africa \\
\hline \multicolumn{7}{|c|}{ Relative export advantage $(R X A)=$ Balassa's $R C A$ index } \\
\hline 1996 & 34.96 & 0.72 & 9.35 & 7.21 & 1.62 & 10.35 \\
\hline 2000 & 19.70 & 0.38 & 27.66 & 7.57 & 2.47 & 13.82 \\
\hline 2004 & 15.02 & 0.67 & 15.16 & 7.62 & 2.29 & 18.76 \\
\hline 2008 & 18.85 & 0.61 & 47.90 & 8.94 & 2.82 & 23.63 \\
\hline 2012 & 7.91 & 0.24 & 41.12 & 8.69 & 5.42 & 23.37 \\
\hline 2014 & 5.81 & 0.25 & 40.87 & 10.15 & 4.16 & 24.48 \\
\hline Average 1996-2014 & 16.11 & 0.58 & 26.24 & 9.45 & 3.38 & 18.73 \\
\hline \multicolumn{7}{|c|}{ Natural logarithm of the relative export advantage (InRXA) } \\
\hline 1996 & 3.55 & -0.33 & 2.24 & 1.98 & 0.48 & 2.34 \\
\hline 2000 & 2.98 & -0.98 & 3.32 & 2.02 & 0.90 & 2.63 \\
\hline 2004 & 2.71 & -0.40 & 2.72 & 2.03 & 0.83 & 2.93 \\
\hline 2008 & 2.94 & -0.49 & 3.87 & 2.19 & 1.04 & 3.16 \\
\hline 2012 & 2.07 & -1.45 & 3.72 & 2.16 & 1.69 & 3.15 \\
\hline 2014 & 1.76 & -1.38 & 3.71 & 2.32 & 1.42 & 3.20 \\
\hline Average 1996-2014 & 2.66 & -0.64 & 3.11 & 2.23 & 1.13 & 2.89 \\
\hline \multicolumn{7}{|c|}{ Relative trade advantage (RTA) } \\
\hline 1996 & 34.96 & 0.54 & 9.35 & 7.08 & 1.44 & 10.32 \\
\hline 2000 & 19.70 & -0.81 & 27.66 & 7.52 & 2.47 & 13.77 \\
\hline 2004 & 15.02 & 0.64 & 15.16 & 6.55 & 2.05 & 18.74 \\
\hline 2008 & 18.85 & 0.47 & 47.90 & 8.57 & 2.60 & 23.52 \\
\hline 2012 & 7.91 & 0.24 & 41.11 & 8.52 & 5.18 & 23.32 \\
\hline 2014 & 5.81 & 0.24 & 40.87 & 10.06 & 4.01 & 24.40 \\
\hline Average 1996-2014 & 16.11 & 0.38 & 26.24 & 9.21 & 3.19 & 18.68 \\
\hline \multicolumn{7}{|c|}{ Revealed competitiveness index (RC) } \\
\hline 1996 & 17.19 & 1.41 & 16.72 & 4.02 & 2.18 & 5.94 \\
\hline 2000 & 16.40 & -1.15 & 17.51 & 4.98 & 7.60 & 5.55 \\
\hline 2004 & 9.03 & 3.15 & 9.39 & 1.96 & 2.25 & 7.17 \\
\hline 2008 & 11.74 & 1.50 & 18.95 & 3.19 & 2.54 & 5.42 \\
\hline 2012 & 16.52 & 6.42 & 8.67 & 3.96 & 3.09 & 6.11 \\
\hline 2014 & 16.19 & 3.21 & 10.27 & 4.71 & 3.37 & 5.66 \\
\hline Average 1996-2014 & 15.04 & 2.76 & 12.72 & 3.98 & 4.02 & 6.15 \\
\hline
\end{tabular}

Source: Author's calculations based on data from the World Bank, WITS (2015)

other suppliers, namely South Africa, Turkey and Greece, the results showed that their orange RXAs have improved steadily, although at slower rates and with less vibrations in comparison to Egypt. The values of orange RXA for Argentina and Turkey showed that they significantly lag behind other orange exporters to Russia in terms of revealed comparative advantage.

The results of the natural logarithm of the relative export advantage and the revealed competitiveness indices in Table 1 further confirmed Egypt's strong export advantage and competitiveness in comparison to other orange suppliers to Russia. In particular, the results of the revealed competitiveness index revealed that Morocco ranks first with an index value of 15.04, followed by Egypt 12.72, South Africa 6.15, Turkey 4.02, 
Greece 3.98 and lastly Argentina 2.76. As an overall analysis of the results of Vollrath's indices during the period 1996-2014, it could be concluded that there are competitiveness gains for the majority of orange suppliers to Russia, albeit to varying degrees. Egypt seemed to be the country that has achieved remarkable improvements in the comparative advantage and competitiveness of its orange exports. Alternatively, there was a loss of competitiveness in Morocco and an obvious lack of comparative advantage of Argentinian orange exports in relation to other exporters, while the values of the indices in certain years are below zero.

\section{Methods}

\section{Orange import allocation model}

One of the most common approaches to estimating demand relationships is based on a direct differential approximation of the demand function, which generates a set of equations that are local first-order approximations of the underlying relationship between prices, quantities and income (Okrent and Alston 2011). Yu et al. (2004) indicate that the Rotterdam model (Barten 1964; Theil, 1965) has become a prominent vehicle for the econometric analysis of patterns of consumer demand and rigorous testing of the utility maximisation theory. Barnett and Seck (2008) point out that the Rotterdam model gained prominence in food demand analysis, thanks to its locally flexible functional form. Moreover, it does not place a priori restrictions on the possible elasticities at a given point and also features enough parameters to approximate elasticities at a given point. The Rotterdam model has therefore been used quite extensively to analyse agrifood demand from different supply sources (e.g. Fonsah and Muhammad 2008; Feleke and Kilmer, 2009; Seale et al., 2013; Clements and Gao, 2015). Surprisingly, the Rotterdam model has to date received less attention in the literature on foreign demand for Egyptian agrifood commodities, while the few studies featuring differentiation in the source of origin have without exception applied the AIDS model (e.g. Elkady and Abd Elmessih 2005; Abu Hatab and Romstad 2014; Abu Hatab and Surry 2015). In this paper, the Rotterdam model was therefore used to analyse the demand relationships between major orange suppliers to the Russian market during the period 1996-2014. In this context and following Seale et al. (1992) and Theil (1980), total orange demand in the estimated model is determined in the first stage, and conditional on total orange expenditures, the demand for oranges from each source is determined in the second stage.

Therefore, assuming that Russia imports orange from $n$ supplying sources and letting $\left(q_{i}\right)$ denote the imported quantity of orange from supplier $i$ and $\left(p_{i}\right)$ denote the import price of orange from supplier $i$, the Rotterdam model can be specified as follows:

$$
\bar{w}_{i t} \mathrm{~d} \log q_{i t}=\theta_{i} D Q_{t}+\sum_{j=1}{ }^{n} \pi_{i j} \mathrm{~d} \log p_{i t}+\varepsilon_{i t}
$$

where $\bar{w}_{i t}=\left(\left(w_{i t}+w_{i, t-1}\right) / 2\right)$ represents the expenditure share of orange imports from supplier $(i)$ in the year $(t)$. In Eq. (5), $d \log q_{i t}=\log \left(q_{i t} / q_{i, t-1}\right)$ and $d \log p_{i t}=$ $\log \left(p_{i t} / p_{i, t-1}\right) . D Q_{t}$ is the Divisia volume index which can be expressed by the following formula: $D Q_{t}=\sum_{i} \bar{w}_{i t} d \log q_{i t}$. The random disturbance term $\left(\varepsilon_{i}\right)$ is assumed to be normally distributed with a mean of zero. The parameter $\left(\theta_{i}\right)$ is the conditional marginal expenditure share on orange imports from supplier $i$ in the total import 
expenditures of the importing market. The parameter $\left(\pi_{i j}\right)$ is the conditional Slutsky price term or relative price effect. This coefficient measures the impact of the price of $j$ th import on the demand for $i$ th import. In Eq. (5), both the parameters $\left(\theta_{i}\right)$ and $\left(\pi_{i j}\right)$ are assumed to be constant for the estimation. In order to conform to theoretical considerations of the Rotterdam model, these coefficients should satisfy the following parameter restrictions:

Adding-up:

$$
\sum_{i} \theta_{i}=1 \text { and } \sum_{i} \pi_{i j}=0
$$

Homogeneity:

$$
\sum_{j} \pi_{i j}=0
$$

Symmetry:

$$
\pi_{i j}=\pi_{j i}
$$

In the estimated demand system, the rest of the world (RoW) equation was omitted because the variance-co-variance matrix of $\left(\varepsilon_{i}\right)$ is singular and parameter estimates are invariant to the omitted equation. The Russian demand for oranges was estimated based on Eq. (5) by using the iterative, seemingly unrelated regression procedure that is equivalent to the maximum likelihood estimation. A means of likelihood ratio test suggested by Judge et al. (1988) was used to test the validity of the imposition of the theoretical restrictions. The conditional expenditure and the compensated and uncompensated price elasticities are calculated as follows:

Conditional expenditure elasticity:

$$
\eta_{i}=\theta_{i} / w_{i}
$$

Conditional Slutsky compensated price elasticity:

$$
\varepsilon_{i j} *=\pi_{i j} / w_{i}
$$

Conditional Cournot uncompensated price elasticity:

$$
\varepsilon_{i j}=\left(\frac{\pi_{i j}}{w_{i}}\right)-w_{i} \eta_{i}
$$

\section{Data and estimation procedures}

Annual data covering the period 1996-2014 were used to estimate Russia's import demand for orange imports from Egypt and other major suppliers. As indicated in the second section of this paper, the selection of the suppliers was based on their shares of expenditure. Data on quantities and values of orange imports by Russia were obtained from the World Bank's World Integrated Trade Solution (WITS) database. Values are on cost, insurance and freight (CIF) basis. Due to the unavailability of reliable data on import prices from each supplier, the unit import value, calculated as import expenditure divided by imported quantity, was used as a proxy for import prices. The final import prices are expressed in Russian roubles based on data from the World Bank's World Development Indicators(WDI) database. Table 2 reports descriptive statistics on the variables of the estimated demand model. 
Table 2 Summary statistics of orange prices and budget shares in the Russian market, 1996-2014

\begin{tabular}{|c|c|c|c|c|c|}
\hline & Mean & Standard deviation & Coefficient of variation & Max. & Min. \\
\hline \multicolumn{6}{|c|}{ Budget shares (measured in percentages) } \\
\hline Egypt & 20.798 & 15.335 & 1.356 & 46.351 & 0.182 \\
\hline Morocco & 22.342 & 13.583 & 1.645 & 49.161 & 4.864 \\
\hline South Africa & 18.488 & 6.586 & 2.807 & 26.409 & 5.481 \\
\hline Turkey & 15.401 & 5.285 & 2.914 & 26.033 & 4.784 \\
\hline Greece & 6.965 & 12.023 & 0.579 & 42.877 & 0.014 \\
\hline Argentina & 4.994 & 4.011 & 1.245 & 12.643 & 0.098 \\
\hline RoW & 16.005 & 6.277 & 2.55 & 31.132 & 8.81 \\
\hline \multicolumn{6}{|c|}{ Prices (measured in Russian roubles/ton) } \\
\hline Egypt & $12,907.735$ & 9955.065 & 1.297 & $28,590.117$ & 417.741 \\
\hline Morocco & $13,864.427$ & $10,463.912$ & 1.325 & $30,362.835$ & 412.566 \\
\hline South Africa & $14,306.010$ & $10,419.957$ & 1.373 & $29,296.336$ & 461.672 \\
\hline Turkey & $13,057.138$ & $10,052.958$ & 1.293 & $29,458.259$ & 429.508 \\
\hline Greece & $14,052.192$ & $11,239.858$ & 1.250 & $30,496.363$ & 359.096 \\
\hline Argentina & $14,169.481$ & $10,389.449$ & 1.364 & $30,430.092$ & 443.415 \\
\hline RoW & $15,075.326$ & $11,102.323$ & 1.358 & $32,176.995$ & 510.027 \\
\hline
\end{tabular}

Source: Author's calculations based on data from the World Bank, WITS (2015) and WDI (2015)

\section{Results}

\section{Parameter estimates of orange import demand equations}

The estimated parameters for the conditional marginal orange import shares for the Russian market, price coefficients and the corresponding asymptotic standard errors are given in Table 3. Preliminary tests indicated that the calculated likelihood ratio test (LRT) values were lower than the corresponding critical value, suggesting that neither

Table 3 Conditional demand estimates for Russian orange imports, 1996-2014

\begin{tabular}{|c|c|c|c|c|c|c|c|c|c|}
\hline \multirow[t]{2}{*}{ Supplier } & \multirow[t]{2}{*}{ Trend } & \multirow[t]{2}{*}{ Expenditure } & \multicolumn{7}{|c|}{ Price effects } \\
\hline & & & Turkey & Egypt & Morocco & South Africa & Argentina & Greece & RoW \\
\hline \multirow[t]{2}{*}{ Turkey } & -0.693 & 0.019 & -0.653 & & & & & & \\
\hline & $(-4.371)$ & $(0.007)^{*}$ & $(0.221)^{*}$ & & & & & & \\
\hline \multirow[t]{2}{*}{ Egypt } & 0.154 & 0.395 & 0.061 & -0.276 & & & & & \\
\hline & $(4.75)^{*}$ & $(0.033)^{*}$ & $(0.175)$ & $(0.065)^{*}$ & & & & & \\
\hline \multirow[t]{2}{*}{ Morocco } & 0.935 & 0.244 & 0.406 & 0.038 & -0.649 & & & & \\
\hline & $(4.732)^{*}$ & $(0.038)^{*}$ & $(0.133)^{*}$ & $(0.017)$ & $(0.350)^{*}$ & & & & \\
\hline \multirow[t]{2}{*}{ South Africa } & 0.011 & 0.153 & 0.022 & 0.023 & 0.024 & -0.545 & & & \\
\hline & $(0.190)$ & $(0.035)^{*}$ & $(0.095)$ & $(0.008)^{*}$ & $(0.098)$ & $(0.118)^{*}$ & & & \\
\hline \multirow[t]{2}{*}{ Argentina } & -0.347 & 0.143 & 0.014 & 0.059 & 0.083 & 0.196 & -0.761 & & \\
\hline & $(-2.712)^{*}$ & $(0.020)^{*}$ & $(0.003)^{*}$ & $(0.030)^{*}$ & $(0.020)^{*}$ & $(0.436)$ & $(0.083)^{*}$ & & \\
\hline \multirow[t]{2}{*}{ Greece } & -0.112 & 0.046 & 0.020 & 0.042 & 0.020 & 0.277 & 0.124 & -0.792 & \\
\hline & $(0.045)^{*}$ & $(0.013)^{*}$ & $(0.0078)^{*}$ & $(0.029)$ & $(0.015)$ & $(0.257)$ & $(0.055)^{*}$ & $(0.301)^{*}$ & \\
\hline \multirow[t]{2}{*}{ RoW } & -0.174 & 0.112 & 0.131 & 0.053 & 0.078 & 0.003 & 0.285 & 0.310 & -0.860 \\
\hline & $(0.032)^{*}$ & $(0.005)^{*}$ & $(0.032)^{*}$ & $(0.385)$ & $(0.023)^{*}$ & $(0.007)$ & $(0.070)^{*}$ & $(0.078)^{*}$ & (0.788) \\
\hline
\end{tabular}

Note: figures within parentheses are asymptotic standard errors *Significance level $\leq 0.05$ 
homogeneity nor symmetry conditions could be rejected. The results presented below in Table 3 are homogeneity and symmetry restricted. The goodness-of-fit of the estimated demand system was measured by calculating the squared $R$ using the following formula as suggested by (McElroy 1977):

$$
R^{2}=1-\frac{1}{1+W /[(T-K)(n-1)]}
$$

A squared $R$ of 0.69 implies that the model can explain the market shares of the total orange imports by Russia. The relative "price effects" are the conditional Slutsky coefficients $\left(\pi_{i j}\right)$, which refer to the change in the market share of supplier $i$ for a unit proportionate change in export price. The "expenditure" refers to the relative share received by supplier $i$ when an additional Russian rouble was added to the expenditures on imported oranges by Russia. Given that the objective of this paper was to examine the demand for Egyptian oranges on the Russian market, the results and their discussions in the following sections primarily focus on the results related to Egypt's equation, with results related to other suppliers discussed where necessary.

The reported estimates in Table 3 show positive and significant relationships between the Divisia index and Russia's orange imports from all suppliers. This implies a positive and significant relationship between Russian expenditure on imported oranges and the quantity of oranges supplied by major exporters. Specifically, a one-rouble increase in Russian expenditure on orange imports was allocated across the seven suppliers and would be relatively large for Egypt (about 40 cents) and Morocco (23 cents), lower for South Africa (15 cents) and Greece (14 cents), and significantly lower for Argentina (5 cents), Turkey ( 2 cents), and RoW (1 cent).

The conditional own-price estimates were negative and statistically significant at the 0.05 level for all suppliers, except for RoW where the estimate was positive but insignificant. According to these results, a one per cent increase in the export price of Egyptian oranges would reduce its market share in the Russian market by about $0.28 \%$. Other suppliers, especially Greece and Argentina, were more sensitive to own-price changes. The conditional cross-price estimates showed that values related to South Africa and Argentina were positive, which implied that a significant competitiveness exists between Egypt and these countries on the Russian market for imported oranges.

\section{Estimated orange import demand elasticities of the orange import demand elasticities}

Abu Hatab and Romstad (2014) illustrated that individual coefficients are likely not to have the usual interpretation or the expected signs because price and income derivatives are non-linear functions of parameters and variables. It is therefore more informative to focus the discussion on the estimated elasticities. Table 4 gives the conditional expenditure elasticities, uncompensated own-price elasticities and their corresponding asymptotic standard errors. The expenditure elasticity estimates for Egypt and Morocco were 1.085 and 1.712, respectively, suggesting that the two countries stand to benefit most from an increase in Russia's expenditure on imported oranges. Specifically, if Russians increase their expenditure on (imported) oranges by $1 \%$, the market share of Egyptian and Moroccan oranges would increase by 1.1 and $1.7 \%$, respectively. Expenditure elasticity estimates for South Africa, Greece and Argentina suggested that their total exports would increase but that their market shares would decrease with increases 
Table 4 Elasticity estimates for Russia's orange imports, 1996-2014

\begin{tabular}{|c|c|c|c|c|c|c|c|c|c|}
\hline \multirow[t]{3}{*}{ Supplier } & \multicolumn{9}{|l|}{ Elasticities } \\
\hline & \multirow[t]{2}{*}{ Expenditure } & \multirow[t]{2}{*}{ Own price } & \multicolumn{7}{|c|}{ Cross price } \\
\hline & & & Turkey & Egypt & Morocco & South Africa & Argentina & Greece & RoW \\
\hline \multirow[t]{2}{*}{ Turkey } & 0.251 & -1.097 & & -0.322 & 0.362 & 0.082 & 0.216 & 0.121 & 0.387 \\
\hline & $(1.443)$ & $(0.430)^{*}$ & & $(0.142)^{*}$ & $(0.176)^{*}$ & -0.082 & $(0.034)^{*}$ & $(0.059)^{*}$ & $(0.524)^{*}$ \\
\hline \multirow[t]{2}{*}{ Egypt } & 1.085 & -0.987 & 0.714 & & -0.588 & 0.123 & -0.501 & -0.131 & 0.276 \\
\hline & $(0.175)^{*}$ & $(0.117)^{*}$ & $(0.107)^{*}$ & & $(0.160)^{*}$ & $(0.061)^{*}$ & $(0.422)$ & $(0.062)^{*}$ & $(0.151)^{*}$ \\
\hline \multirow[t]{2}{*}{ Morocco } & 1.712 & -0.872 & 0.914 & -0.802 & & -0.598 & -0.473 & -0.266 & 0.385 \\
\hline & $(0.269)^{*}$ & $(0.103)^{*}$ & $(0.488)^{*}$ & $(0.191)^{*}$ & & $(0.161)^{*}$ & $(0.281)$ & $(0.234)$ & $(0.087)^{*}$ \\
\hline \multirow[t]{2}{*}{ South Africa } & 0.477 & -0.867 & -0.439 & 0.395 & 0.177 & & 0.125 & 0.255 & -0.123 \\
\hline & $(0.225)^{*}$ & $(0.061)^{*}$ & $(0.286)$ & $(0.002)^{*}$ & $(0.025)^{*}$ & & $(0.089)$ & $(0.203)$ & $(0.310)$ \\
\hline \multirow[t]{2}{*}{ Argentina } & 0.204 & -0.471 & 0.534 & -0.222 & 0.175 & 0.125 & & 0.337 & -0.682 \\
\hline & $(0.110)^{*}$ & $(0.133)^{*}$ & $(0.060)^{*}$ & $(0.288)$ & $(0.104)^{*}$ & $(0.089)$ & & $(0.181)^{*}$ & $(0.242)^{*}$ \\
\hline \multirow[t]{2}{*}{ Greece } & 0.316 & -0.563 & 0.113 & 0.242 & 0.264 & 0.143 & -0.284 & & -0.231 \\
\hline & $(0.128)^{*}$ & $(0.084)^{*}$ & $(0.44)^{*}$ & $(0.381)$ & $(0.012)^{*}$ & $(0.299)$ & $(0.173)^{*}$ & & $(0.038)^{*}$ \\
\hline \multirow[t]{2}{*}{ RoW } & 0.753 & -0.241 & 0.382 & -0.562 & 0.258 & -0.457 & -0.314 & 0.181 & \\
\hline & $(0.599)$ & $(0.221)$ & $(0.157)^{*}$ & $(0.413)$ & $(0.121)^{*}$ & $(0.345)$ & $(0.306)$ & $(0.382)$ & \\
\hline
\end{tabular}

Note: figures within parentheses are the asymptotic standard errors

*Significance level $\leq 0.05$

in Russian demand for imported oranges. With respect to Turkey and RoW, the estimated expenditure elasticity coefficients were positive but statistically insignificant, implying that an increase in Russian expenditure on orange imports would not favour these suppliers.

Own-price elasticity estimates for all orange suppliers to Russia, except for RoW, were negative and statistically significant. Moreover, the estimates for all suppliers are price inelastic with the exception of Turkey (-1.097). Egypt's close-to-unity own-price elasticity implied that if Egypt reduces (increases) the price of its orange exports to Russia by $1 \%$, its market share increases (decreases) by $0.987 \%$. The cross-price elasticity estimate for Egypt with Turkey (0.714) indicated that its oranges are a strong substitute for Turkish oranges on the Russian market. Moreover, the positive but low value of the cross-price elasticity (0.123) between Egypt and South Africa indicated limited competition between Egyptian and South African oranges. These findings imply that Russia tends to switch to orange imports from Turkey and South Africa when Egyptian oranges become relatively expensive. In contrast, the negative sign in the cross-price elasticity coefficient for the Egypt-Morocco, Egypt-Greece and Egypt-RoW pairs indicated a complementary relationship between their oranges on the Russian market.

\section{Discussion and conclusions}

Recent years have seen closer diplomatic relations between Egypt and Russia that have led to a significant growth in their bilateral agricultural trade. As one of the world's leading producers and exporters of oranges, such trade growth represents an opportunity for Egypt to promote its orange exports to Russia. Moreover, in conjunction with EgyptianRussian bilateral agricultural trade growth in recent years, Russia imposed import embargos on agricultural and food commodities from several countries, creating a supply gap of 
around $25 \%$ on the Russian orange market, thus representing further export opportunities for Egyptian oranges. Motivated by these developments in the Russian orange market, this paper used a Rotterdam import allocation model to analyse demand relationships among major orange suppliers to Russia during the period 1996-2014.

The empirical results of the Rotterdam model suggested that the orange quantities and market shares of Morocco and Egypt would increase the most if Russia were to allocate a larger budget to the import of oranges. The results also showed that Egypt's export prices had a significant influence on its market share in the Russian market for imported oranges. Previous studies on the export performance of Egyptian agricultural commodities have pointed out that the lack of competitive prices is one of the greatest challenges hindering the access of Egypt's agricultural commodities to foreign importing markets (Soliman and Bassiony 2012; Torayeh 2013; Abu Hatab and Hess 2013). With Egypt's close-to-unity own-price elasticity for oranges, it may be possible to increase Russian demand for Egyptian oranges by implementing policies that help farmers increase their orange production and yield sustainably and cost-effectively. In this respect, it would be necessary to adopt innovative agricultural policies to increase productivity through the implementation of modern and globally agreed production techniques, including irrigation, fertilisation and pest management practices. Moreover, investment in infrastructure and post-harvest services is crucial to connect orange production areas more effectively with their markets and reduce transportation cost and post-harvest losses. Furthermore, improved Egypt-Russia diplomatic and trade relations in recent years and ongoing (agricultural) trade liberalisation negotiations represent a sound opportunity for Egypt to discuss these market access issues in order to enable Egyptian exporters to reduce the prices at which they offer their oranges on the Russian market.

The estimates of cross-price elasticity in particular revealed that Turkey and South Africa are Egypt's main competitors on the Russian market for imported oranges. Russia tends to switch to orange imports from these suppliers when Egyptian oranges become relatively expensive. Given that Turkish oranges are currently excluded from the Russian market, they do not present a competitive threat to Egyptian orange exports to Russia at the moment. A removal of the embargo would likely expose Egyptian oranges to fierce competition with Turkey. This is because Turkey would benefit from its geographical proximity to Russia that gives it a competitive advantage by eliminating the need for refrigerated transportation and therefore allowing it to undercut the Egyptian export price significantly (Gressel 2012). With respect to South Africa, the smaller influence of its competitiveness effect on Egyptian orange exports to Russia might be partially attributed to the fact that it has different production and export seasons ranging from July to September compared to many varieties of Egyptian oranges that are harvested in December. However, Egypt's relative proximity to Russia reduces transportation costs and gives Egypt a competitive advantage that mitigates the competition effect of South Africa (King-Okumu and Aboukheira 2015).

Taking into account the structural changes that the Russian orange market is currently undergoing, competition between traditional exporters and with new entrants is likely to intensify. Although competition may represent a threat to Egyptian orange exports to Russia, it could also act as an efficiency-enhancing factor and a positive driver of innovation that could enhance export competitiveness. In this respect, upgrading the 
orange value chain, adopting agro-processing technologies, enhancing the technical and organisational capacity of farmers and exporters and strengthening the institutional framework of the orange export sub-sector are important strategies that could enable Egyptian exporters to move up the value chain, offer higher value-added oranges and improve their competitiveness on the Russian market.

Furthermore, despite the calculation results of the revealed comparative advantage in the second section of this paper, indicating that Egypt enjoys a strong comparative advantage in orange exports in comparison to other orange suppliers to Russia, these results should be interpreted with caution since the existence of a comparative advantage alone certainly does not guarantee that a country's exported commodity will be able to "compete" successfully. A country's comparative advantage in a given commodity could alter over time due to changes in any of the other determinants of comparative advantage, such as demand patterns; the level of technology and production systems, government policies, and food safety; and quality standards among others (Cai and Leung 2007). In particular, non-tariff barriers (NTBs) such as sanitary and phytosanitary (SPS) measures are increasingly becoming a major determinant of the performance and market share of Egyptian agricultural exports to Russia and other importing markets (Bassiony 2012; Torayeh 2013). In this context, Trienekens and Zuurbier (2008) illustrated that the growing proliferation and stringency of food safety and quality standards in global importing markets have brought additional challenges to developing countries and raised concerns about their ability to cope with export requirements. Accordingly, the international fresh produce market has increasingly become highly competitive and sophisticated, and compliance with these ever-rising standards has become a critical factor that can adversely affect the competitiveness of exports from developing countries (Martinez and Poole 2004; Okello and Swinton 2007). With respect to the Russian market, Vinokurov et al. (2015) classified and assessed the impact of NTBs in the members states of the Eurasian Economic Commission (including Russia) and concluded that SPS measures represent one of the most important NTBs that increase the cost of exports to Russia on a significantly larger scale than other NTBs and therefore affect the access and competiveness of foreign exporters. Such NTBs could negate the positive effects of ongoing Egypt-Russia trade liberalisation efforts with Egyptian orange exports and should therefore be given priority within the context of these efforts, as well as in the ongoing negotiations aimed at the establishment of a free trade area between Egypt and the Eurasian Customs Union. Moreover, while the primary focus of this paper has been on price relationships between orange suppliers to Russia, more research using different and approaches is needed to provide a quantitative assessment of the trade implications of NTBs on the access and competitiveness of Egyptian orange exports on the Russian market.

Competing interests

The author declares that he has no competing interests.

Received: 23 February 2016 Accepted: 11 October 2016

Published online: 26 October 2016

References

Abu Hatab A, Hess S (2013) Opportunities and constraints for small agricultural exporters in Egypt. Int Food Agribus Manag Rev 16:77-100

Abu Hatab A, Nsanimana A (2016) A dynamic analysis of Egyptian orange exports to Russia: an ARDL approach. Agricultural Economics Review, the Greek Association of Agricultural Economists. In Press. 
Abu Hatab A, Romstad E (2014) Competitiveness analysis of Egyptian cotton exports with special focus on the Chinese market. China Agri Econ Rev 6:248-263. doi:10.1108/CAER-02-2013-0026

Abu Hatab A, Surry Y (2015) The determinants of import demand for Egyptian potatoes in the European Union. In: Proceedings of the XVIII International Symposium on Horticultural Economics and Management. The International Society for Horticultural Science, Alnarp, Sweden, May 31-June 3, 2015

Balassa B (1965) Trade liberalization and "revealed" comparative advantage. Manch Sch Econ Soc Stud 33:99-123

Barnett WA, Seck O (2008) Rotterdam model versus almost ideal demand system: will the best specification please stand up? J Appl Economet 23:795-824

Barten AP (1964) Consumer demand functions under conditions of almost additive preferences. Econometrica 32:1-38

Bassiony H (2012) Impact of non-tariff barriers on Egyptian agricultural trade. In: Proceedings of Minia International Conference for Agriculture and Irrigation in the Nile Basin Countries. El-Minia University, Minia, Egypt, March 29-29, 2012

Cai, J, Leung P (2007) A review of comparative advantage assessment approaches in relation to aquaculture development. In: Leung et al. quality standards among others (ed) Species and System Selection for Sustainable Aquaculture, i st edn., Blackwell Publishing, Ames, lowa, USA. doi: 10.1002/9780470277867.

Clements KW, Gao G (2015) The Rotterdam demand model half a century on. Econ Modelling 49:91-103

Elkady S, Abd Elmessih E (2005) The competitive ability of the Egyptian potatoes exports in the foreign markets. Egypt J Agri Econ 15:347-368

FAOSTAT (2016) Food and agriculture organization of the United Nations' statistical database. FAO, Rome, http://faostat3.fao.org. Accessed 26 July 2016

Feleke ST, Kilmer RL (2009) The Japanese market for imported fruit juices. Int Food Agribus Manag Rev 12:1-28

Fonsah EG, Muhammad A (2008) The demand for imported apple juice in the United States. JFood Distrib Res 39:57-61

GRC, Global Reach Consulting (2012) Russian and world fresh fruit market Russia. GRC, Moscow

Gressel J (2012) Egypt-citrus annual. US Department of Agriculture (USDA), USDA Foreign Trade Service. Global Agricultural Information Network, Washington DC

Hamida M (2012) Determinants of external demand for Egyptian exports of oranges in the world market. J Appl Sci Res 8:5730-5735

Hamza M (2014) Egypt's orange exports benefiting from Russia's ban on EU imports. USDA Foreign Trade Service, Global Agricultural Information Network, Washington DC

Hamza M (2015) Egypt-citrus annual. USDA Foreign Trade Service, Global Agricultural Information Network, Washington DC

Hassan A, Mohamed A, Elgebaly M, Hassan H (2010) Economic analysis of the current situation for the production, export and the competitiveness of Egyptian oranges in global markets. Aust J Basic Appl Sci 4:5797-5804

Honkanen P, Voldnes G (2006) Russian consumers' food habits: results from a qualitative study in Moscow. Norwegian Institute of Fisheries and Aquaculture Research, Tromso

Ilyina S (2011) Russians love citrus but U.S. share tiny. USDA Foreign Trade Service, Global Agricultural Information Network, Washington DC

Judge GG, Hill RC, Griffiths W, Lutkepohl H, Lee TC (1988) Introduction to the theory and practice of econometrics. John Wiley \& Sons, New York

King-Okumu C, Aboukheira A (2015) Challenges to achieving sustainable exports of fruits from small-holdings under water scarcity conditions of the Southern Mediterranean. In: Paciello MC (ed) Building sustainable agriculture for food security in the Euro-Mediterranean area. Edizioni Nuova Cultura, Rome

Kolchevnikova O (2010) Russian retail food sector nears rebound. USDA foreign agricultural service, Global Agricultural Information network, GAIN report number: RSATO1003, USDA, Washington

Laursen K (2015) Revealed comparative advantage and the alternatives as measures of international specialization. Eurasian Bus Rev 5:99-115

Leromain E, Orefice G (2014) New revealed comparative advantage index: dataset and empirical distribution. Int Econ 139:48-70

MALR (2015) Annual agricultural statistics bulletin. MALR, Cairo

MALR, Ministry of Agriculture and Land Reclamation (2013) Annual agricultural statistics bulletin. MALR, Cairo

Martinez MG, Poole N (2004) The development of private fresh produce safety standards: implications for developing Mediterranean exporting countries. Food Policy 29:229-255

McElroy MB (1977) Goodness of fit for seemingly unrelated regressions: a generalization. J Econometrics 6:381-387

Okello JJ, Swinton SM (2007) Compliance with international food safety standards in Kenya's green bean industry: comparison of a small-and a large-scale farm producing for export. Appl Econ Perspect Policy 29:269-285

Okrent AM, Alston JM (2011) Demand for food in the United States: a review of literature, evaluation of previous estimates, and presentation of new estimates of demand. Giannini Foundation of Agricultural Economics Monograph 48, Berkeley, California

Parker JW (2015) Understanding Putin through a Middle Eastern looking glass. Strategic Perspectives issue 19, Center for Strategic Research, Institute for National Strategic Studies, National Defense University, Washington, DC

Rudolf M (2015) Egypt's citrus sector is expanding. Online article., Agroberichten Buitenland, http://www.agroberichtenbuitenland.nl/cairo/egyptes-citrus-sector-groeit/. Accessed 28 July 2016

Seale JL, Sparks AL, Buxton BM (1992) A Rotterdam application to international trade in fresh apples: a differential approach. Agric Resour Econ Rev 17:138-149

Seale JL, Zhang L, Traboulsi MR (2013) US import demand and supply response for fresh tomatoes, cantaloupes, onions, oranges, and spinach. J Agri Appl Econ 45:435-452

Soliman I (2013) Oranges sector in Egypt: performance and policies. In: report number D20 (Policy for Competitiveness of the Fresh Orange Export Sector in Mediterranean Partner Countries), USTAINMED Project (Sustainable agri-food systems and rural development in the Mediterranean Partner Countries). https://sustainmed.iamm.fr/index.php/publications/project-reports. Accessed 02 Oct 2016.

Soliman I, Bassiony (2012) Egyptian agricultural exports competitiveness. MPRA Paper No. 66820. https://mpra.ub.uni-muenchen. de/66820/ Accessed 30th July 2016

Theil H (1965) The information approach to demand analysis. Econometrica 33:67-87 
Theil H (1980) The system-wide approach to microeconomics. The University of Chicago Press, Chicago

Torayeh NM (2013) The competitiveness of the Egyptian agricultural export in the EU market: should Egypt diversify its trade pattern? Appl Econ Int Dev 13:129-148

Trienekens J, Zuurbier P (2008) Quality and safety standards in the food industry, developments and challenges. Int J Prod Econ 113:107-122

Vinokurov E, Demidenko M, Pelipas I, Tochitskaya I, Shymanovich G, Lipin A (2015) Assessing the impact of non-tariff barriers in the EEU: results of enterprise surveys. Report 30, EDB Centre for Integration Studies, EDB, Saint Petersburg

Vollrath TL (1991) A theoretical evaluation of alternative trade intensity measures of revealed comparative advantage. Weltwirtschaftliches Archiv 127:265-280

WDI, World Development Indicators Database (2015). The World Bank. Available at: http://databank.worldbank.org/data/ reports.aspx?source=world-development-indicators.

WITS, World Integrated Trade Solution, (2015). The World Bank. Available at: http://wits.worldbank.org/wits/.

WITS, World Integrated Trade Statistics database (2016) World Bank, Washington DC. http://wits.worldbank.org/. Accessed 23 July 2016.

Yu W, Hertel TW, Preckel PV, Eales JS (2004) Projecting world food demand using alternative demand systems. Econ Modelling 21:99-129

Submit your manuscript to a SpringerOpen ${ }^{\circ}$ journal and benefit from:

- Convenient online submission

- Rigorous peer review

- Immediate publication on acceptance

- Open access: articles freely available online

- High visibility within the field

- Retaining the copyright to your article

Submit your next manuscript at $\boldsymbol{\nabla}$ springeropen.com 